\title{
Influencing Factors for Malaysian Muslim Women Consumers in Purchasing of Non-Certified Halal International Brand Makeup Products in Mid Valley Megamall Kuala Lumpur
}

\author{
Nor Awanis Idris ${ }^{1 *}$, Mohamad Aizat Jamaludin ${ }^{1}$, Noor Yuslida Hazahari ${ }^{1}$, Betania Kartika ${ }^{1}$ \\ ${ }^{1}$ International Institute for Halal Research and Training, International Islamic University Malaysia, Jalan \\ Gombak, 53100 Kuala Lumpur, Malaysia. \\ *Corresponding author: Nor Awanis Idris, International Institute for Halal Research and Training (INHART), \\ International Islamic University Malaysia (IIUM), Jalan Gombak, 53100, Selangor, Malaysia; \\ awanisidris@yahoo.com
}

\begin{abstract}
Malaysia is expected to witness a greater demand for halal products due to increasing awareness of Islamic practices among the citizen. Malaysian Muslim women consumers spend more on cosmetics especially on those makeup products by international brands. For a Muslim, it is an obligatory to practice using only halal cosmetics for makeup products. Unfortunately, the halal awareness of non-food (cosmetics) is lacking among the consumers as compared to food products. This reason being that food is considered as consumable goods, while cosmetic is to be used on face and body; for external application and nothing internal. The main issue surrounding this strict practice (makeup products on face and body) concerns on the source of ingredients, either from halal or haram source. Ingredients sourced from haram materials will nullify the daily prayers of a Muslim. A study has shown that the customer's intent to purchase cosmetic with non-certified halal is without a doubt if the halal products are not made available in the market. This eventuates to the infrequent use of halal logo by companies that produce makeup products and existing incidents of fraudulent pertaining to the halal logo in the market. Thus, the purpose of this study is to identify the factor influencing Malaysian Muslim women in purchasing of noncertified halal international brand makeup products. This study applied a qualitative approach based on library study and face-to-face interview with 20 Malaysian Muslim women consumers. The interview was recorded, transcribed, and applied to a content analysis. As a result, the findings demonstrated that the factor influencing Malaysian Muslim women in purchasing of non-certified halal international brand makeup products are divided into two, which are the (i) internal and (ii) external factors. Internal factors include quality, trust, brand, loyalty, price, effectiveness, safety, confidence, variety, and ingredients while external factors derived from the influencers such as makeup artists, internet celebrity, public figures, well-known entrepreneurs, bloggers, and Instagram-famous figure.
\end{abstract}

Keywords: Halal cosmetics; international makeup products; Malaysian muslim women; and Halal awareness

Received: $18^{\text {th }}$ March 2020

Citation: Idris NA, Jamaludin MA, Hazahari NY, et al. Influencing factors for Malaysian Muslim women

Accepted: $2^{\text {nd }}$ October 2020 consumers in purchasing of non-certified halal international brand makeup products in Mid Valley Megamall Kuala Lumpur. J Halal Ind Serv 2020; 3(1):

Published Online: $22^{\text {nd }}$ October 2020 a0000117. https://doi.org/10.36877/jhis.a0000117 


\section{Introduction}

Cosmetic products that manufactured by non-Muslims are widely used among Muslims all over the world (Swidi et al., 2010). Unfortunately, majority of the Muslims are not giving enough attention on the halal ingredients in the cosmetic products which pose serious challenges afterwards. Where the awareness is increasing, Muslim consumers started to have a shift of behaviour by having demand for halal cosmetic products (Hashim \& Musa, 2013; Mohezar et al., 2016). Thus, many companies in the cosmetic industry are gearing towards producing halal cosmetic products according to the Shari'ah to fulfil the demand. Unfortunately, in general nowadays, halal certified makeup products are still inferior in quantity and are hardly available for purchase. Most of the Muslim consumers will eventually purchase products without halal certification when there are no halal products available (Ahmad et al., 2015). This finding has also been supported by Hunter (2012) as cited in Kaur (2018), which stated that when there is no other choice, Muslim consumers intent to buy products that do not have halal certification.

Halal is no longer a purely religious issue. It is in the realm of business and trade, and it is becoming a global symbol for quality assurance and lifestyle (Hassali et al., 2015). Indonesia, Thailand, Philippines, Vietnam and Malaysia are the five countries under the Association of Southeast Asian Nations (ASEAN) which are intensively promoting halal cosmetic variants such as in skincare, makeup, fragrances and hair care products (Kaur, Osman \& Maziha, 2014).

In Malaysia, cosmetic industry existed since about 30 years ago (Swidi et al., 2010). Cosmetics which consists of makeup, perfume, toothpaste, shampoo, and deodorant is used for enhancing features without causing any problems to the body (Zaidun \& Hashim, 2017). Cosmetics come in a very wide range of products from cleanser, toner, serum, moisturizer to foundation, powder, lipstick, eye liner, eye shadow, blusher including mascara and it will not end there. Instead, the variants will keep on increasing from time to time, based on the customer's demand (Teoh \& Md Harizan, 2017). Essentially, makeup is one of the confidence factors in empowering how most ladies feel on an average everyday living. Cosmetics are more frequently devoured by ladies than men as the objective clients of restorative organizations are among the female customers (Hashim \& Musa, 2014).

Cosmetic products are comprised of both local and international brands. Some of the local brands in cosmetic products are owned and manufactured by local companies and several others are of that produced abroad. While some of the international cosmetic brands are also owned by the international companies, they are also manufactured locally and only several of the products are manufactured abroad. Besides, several imported brands of cosmetic products recorded an increased in number securing its place in the local Malaysian market. This is due to the overwhelmed emphasize among local consumers on the beauty and personal appearance towards international cosmetic brand (Ghafur, 2017). 
Given the significance of halal labelled cosmetics, the implementation of halal logo and marketing strategies towards it are still barely evidenced in the Malaysian cosmetic industry (Majid et al., 2015). The misuse of halal logo is a growing concern because it will affect the customer's trust towards halal products entirely. Thus, it is vital to educate customers on how to distinguish fake halal logos.

Besides, Kaur (2018) stated that halal is not a supreme priority to the consumers when purchasing the cosmetic products as they are more concern on the affordable and cheaper price, material of a good quality and those from the in-trend, popular brands. This shows that the level of halal awareness among the consumer in Malaysia towards halal cosmetics is still low. Therefore, halal cosmetic is associated with numerous requirements and factors according to the Shari'ah, such as halal principles, product reliability, product commitment, intention to choose halal cosmetic products, trust, environmental friendliness, attitude, religious belief, and product innovation. This research will study on the factors that influence Muslim consumers on choosing non-certified halal brand makeup products.

The purpose of the study is to determine influencing factors for Malaysian Muslim Women Consumers in Purchasing of Non-Certified Halal International Brand Makeup Products.

\section{Methods}

A qualitative research that focused on a descriptive study had been conducted. A descriptive research aims to depict an occurrence and its features (Nassaji, 2015). In order to achieve the research objectives, (i) opinions, (ii) attitudes, and (iii) perspectives of an individual must be collected through interview sessions. The data was composed and analysed qualitatively.

\section{Sample}

Interview type that used in this study is structured interviews based on set of questions (Tim, 2011). Basically, interviewer would ask the same questions to all the informants and then to compare the answers between them thus highlighting results from the interview. This method has some ground rules which the interviewer will have to explain the questions in a standardized way, and it must be done within the interview session. In this case, the interviewer could not be bias. The interviewer could not give any answer or hint to the interviewee. The questions must be finalized in a way that it could not be changed. The participants were selected based on the criteria of Malaysian Muslim women and user of international brand makeup products.

Besides, this study also used purposive sampling. Babbie (2016) explains the purposive sampling as one of the non-probability sampling. In this purposive sampling, the researcher selects the informants that are useful and could represent the study through the 
researcher's basic discretion includes gender, background and type of consumer. General open-ended questions are asked to allow the participants to create options for responding or voicing their experiences and perspectives. After that, information is recorded, and transcribed for analysis. The interview questions were prepared based on the research objectives and the literature review.

The interview session was conducted in Mid Valley Megamall. The Megamall is selected because it is adjacent to the Federal Highway, the busiest highway in Klang Valley during rush hour as it connects people from/to Kuala Lumpur. Even though it is not the biggest mall in Klang Valley, it has more public transportation options; Keretapi Tanah Melayu Berhad (KTMB), RapidKL LRT Kelana Jaya Line, public bus service and Mid Valley Megamall's free shuttle bus. Mid Valley Megamall comprises of 247 tenants that includes 202 stores and 44 kiosks. This mall has been visited by 60,000-70,000 shopper's weekdays while the number can be up to 100,000 shoppers for weekends and a total of 3 million shoppers per month. So, the selection of this area will get a representative of perception among Malaysian Muslim women consumers regarding on purchasing of noncertified halal international brand makeup products.

\section{Demographic and Descriptive Analysis}

Table 1 shows the demographic information of informants based on characteristics, category and frequency.

Table 1. Demographic Information of Informants.

\section{CATEGORY}

FREQUENCY
CHARACTERISTICS

Age

Education

Hometown

Education
然
20-25 years old

26-30 years old

31-35 years old

36-40 years old

STPM

Diploma

Degree

Selangor

Kelantan

Johor Bharu

Perak

Penang

Pahang

Negeri Sembilan
12

6

1

1

1

8

11

5

7

2

2

1

2 
Salary Range

Periods of Staying in Kuala Lumpur
Student/Housewife 3

Less than RM 2,000 8

RM 2,000-RM 4,000 8

RM 4,000-RM 6,000 1

Below 1 year 3

$1-10$ years $\quad 15$

11-20 years 1

21-30 years 1

For this study, there were total of 20 informants who were selected based on these following criteria: (i) Malaysian Muslim women and (ii) User of international brand makeup products. As illustrated from the table 1, the age of informants varies from 20 years old to 37 years old. They came from various educational backgrounds as well, STPM, Diploma, and Degree. Table 1 also portrays that most of them came from another state, and only 5 of them were from Selangor. Even so, they spent most of their life here as shown in the table, 15 of them were staying in Kuala Lumpur for 1 to 10 years. The precursor factor that influenced awareness of using halal cosmetics seems to be the socio demographic profile (Phuah \& Jusoh, 2013).

\section{Instrument}

The instrument used in this study was interview. The interviews were conducted by the researcher and the interview questions were designated by the researcher based on the theoretical framework and the literature review. At the beginning of the interviews, the participants were asked for some demographic questions such as name, age, hometown, education, salary range, and periods of staying in Kuala Lumpur. The interview questions consist of two parts align with the research objectives. The first part of the questions was related to the consumer's purchasing factor of international brand makeup products while the second part was related to the consumer's awareness on halal certified makeup products. All the interview questions were translated by the researcher into Bahasa Melayu as the informants were Malaysian. The interview questions were then validated by expert for improvement.

\section{Data Analysis Procedure}

Data analyses should be based on the research questions and the research design selected for the study. The researcher had specified the procedures for reducing and coding the data. In this study, content analysis was applied to transcribe and interpret the interview result. 


\section{Interview Analysis}

The structured of interviews were transcribed and analysed using the method of qualitative analysis. In the organizing and the familiarizing stage, the interviews were transcribed and translated into English from Bahasa Melayu. In the coding and reducing stage, informant responses were grouped according to the research questions. After that, the codes were formed in relation to the type of informants purchasing factors of international brand makeup products such as "quality", "long lasting", "brand", "trust", "affordable" and "confident". These codes were selected because it has been frequently mentioned by the informant. In the interpreting and representing stage, the data were reported using narratives.

\section{Results and Findings}

\section{International Brand Makeup Products}

Basically, 2015 marked a total of US $\$ 2.24$ billion trade volume for personal care and cosmetic products in Malaysia. The main exporters for personal care and cosmetics products to Malaysia are China, Thailand, France, EU28, the United States, South Korea and Japan. The demands for cosmetic sectors are expected to be positively increasing starting 2016 onward (Lee et al., 2019).

Cosmetics or makeup can be defined as "articles intended to be rubbed, poured, sprinkled or sprayed on, introduced into or otherwise applied to the human body for cleansing, beautifying, promoting attractiveness, or altering the appearance" (FD\&C Act, 2012). International makeup products are also known as imported makeup products. In this case, the imported products are from worldwide exporters to Malaysia. Makeup is mostly applied on the face. Other makeup's cosmetic includes nail enamel. Face makeup has become into the category of base makeup and point makeups. Foundation, Face powder, Lipstick, Blusher, Eye Shadow, Eye Liner, and Nail Enamel are all categorized as makeup product (Ali, Halim, \& Ahmad, 2016).

According to Hornby (2010) makeup is a substance used to make the face more attractive or to change the appearance and it is mostly used by women. Therefore, the purpose of producing makeup products is the same be it manufactured locally or abroad. The difference is more on the acceptance and the needs for consuming the brand either international or local makeup products although, there are several differences between range and functions of a makeup product.

\section{Range and Functions of Makeup Products}

Every single person in this world would have a different range of makeup products according to their own preferences and their needs. Some would only use basic products such as foundation and lipstick. Instead, the influencers and makeup artists used a wide range of makeup products. Basically, the arrangement of the products was according to its functions. 
The range for most of the international brand makeup products and their functions are as below (Hornby, 2010):

a) Primer

This product is used to create an extra layer between the skin and makeup. Eventually, it helps makeup to last all day long, smoothen the skin's surface for an easy application of the makeup afterwards and produce an even skin tone. Hornby (2010) defines primer as a type of paint placed on a wood or metal before it is painted to make it stay longer on the surface. The primer could be applied to the face, eyes, lips and lashes. Basically, this product acts as the first step in makeup process as it will prime the skin before the actual makeup starts. They come in different types such as illuminating primers, mattifying primers, colour-correcting primers, long-wearing primers, hydrating primers and pore-minimizing primers.

\section{b) Foundation}

Foundation is a skin-coloured cream used on face before putting on anything else. Foundation's range comes in stick, liquid, cream and powder form. Despite its different range, the functions remain the same. It was used to even out the skin tone, cover the flaws and to some extent, changing the original skin tone. In addition, it will make the skin to be uniformed in colour as well. The foundation comes in variety of shades and it is applied right after the primer.

\section{c) Concealer:}

Concealer is a skin-coloured cream as well, but it is to cover the marks on the skin or dark circles under the eyes. Concealer also called as a colour corrector, is a bit thicker than the foundation. It is used to cover dark circles, age spots, large pores and also the visible blemishes. It comes in liquid and powder form and has wide shades to suit the skin colour.

\section{d) Powder}

To set up the makeup after applying the foundation and concealer, powder is used with the purpose of controlling the oil and gives a matte finishing effect on the skin. It should be absorbed into the skin well. The usage of a face powder will help to reduce the visibility of wrinkles and lines. It was supposed to cover the minor imperfections on one's face and in some cases, will stay longer on the face so that the re-powdering is unnecessary. Moreover, it will also enhance the skin appearance by reducing the visibility of discoloration as well (Elmarzugi et al., 2013; Hamedi et al., 2019).

e) Blusher or Rouges

Blusher is also called as rouges or blushes and it is basically used to make the cheeks red or pink. It is to set off the younger and healthy skin with the effect of rosy freshness as well. 
This blusher comes in various shades and types such as in liquid, cream and solid. Rouges that come in a solid form are convenient to use rather than in other forms. Some people prefer their cheeks to look natural while others prefers it to be the centre of attraction. They applied rouges on both cheeks using a specific makeup brush or a puff. The usage of a blusher will make one look younger and pretty (Hamedi et al., 2019).

\section{f) Eyeliner}

Eyeliner is used in makeup to make the eyes look smaller or wider. It can be drawn above upper lashes or at the lower lashes as well and to some extent inside the water lines itself. Eyeliner is considered as makeup, usually black in colour that is drawn around the eyes either at the upper or lower lashes to make it more appealing and pleasing. It could change the eye shape and draw attention to it. The common colour ranges for eyeliner are black, brown, and grey while others such as pastels, frosty silver, gold, white and glitter colour.

\section{g) Eyebrow Pencil}

A makeup process is considered incomplete without the eyebrows' grooming. The function of eyebrow pencil is to groom the eyebrows into a certain shape that preferred by the user itself (Hornby, 2010). Eyebrow pencils are used to darken the eyebrows, typically in black. The proportion of waxes in the eyebrow pencils gave the hard effect which makes it easier to be constructed into a perfect point of eyebrows (Hamedi et al., 2019).

\section{h) Eye shadow}

Eye shadow comes in plenty of colours and textures which could be applied on the eyelids and under the eyebrows. Usually, eye shadow is made in a form of powder such as compressed or loose powders, but it could also in certain cases made from liquid, pencil cream, emulsions, sticks and mousse. (Hamedi et al., 2019).

\section{i) Mascara}

Every woman wished to have long eyelashes and that is where the mascara comes into place. It will thicken the eyelashes and to a certain degree, the eyebrows as well as to make it more appealing. Basically, most users will choose the black mascara because it looks natural and it could also come in another colour such as purple, and pink to create an extraordinary look.

\section{j) Highlighter}

The highlighter in makeup products is used for face contouring. It will create angles and depth on one's face. It comes in many forms but the most frequently used is in the powder form. It is applied to cheekbones, nose and jawline to make it more appealing and create a difference in features. 


\section{k) Lipstick}

Lipsticks usually come in way more various range of colours than other makeup products. It will add colour and texture to the lips and in some cases, it will even make the lips become matte, satin, and lustre. According to (Hamedi et al., 2019) lipstick helps in brightening the lip's colour and will reduce irritation to the lips.

\section{Type of Muslim Consumers of International Brand Makeup Products}

Based on the interviews, types of Muslim consumers that chose international brand makeup products are among those women with career. Most of them are working in Kuala Lumpur and had been staying in Kuala Lumpur for quite some time now. Their range of age was around 20 to 37 years old, respectively.

\section{Factors Influencing Malaysian Muslim Consumers in Choosing International Brand Makeup Products}

Table 2 below shows internal and external factors which influence Malaysian Muslim consumers on choosing international brand makeup products.

Table 2. Internal and External Factors influencing Malaysian Muslim Consumers on choosing International Brand Makeup Products

No. Internal Factors $\quad$ External Factors

\begin{tabular}{ccc}
\hline 1. & Quality & $\begin{array}{l}\text { Influencers (makeup artists, internet } \\
\text { celebrities, public figures, well-known } \\
\text { entrepreneurs, bloggers, and insta-famous) }\end{array}$ \\
2. & Trust & \\
3. & Brand & \\
5. & Poyalty & \\
6. & Effectiveness & \\
7. & Safety & \\
8. & Confidence & \\
9. & Variety
\end{tabular}

Table 2 portrays the internal and external factors of Malaysian Muslim women in choosing international makeup products. Internal factor derives from the person in the light of one's own commitments, desires or goals. Quality is the most frequent answers for 
selecting the international brand makeup products. There are 14 out of 20 informants chose quality as the internal reason, while others indicated trust, brand, loyalty, price, effectiveness, safety, confidence, variety, and ingredients as the factors mentioned.

Consumer's satisfaction derives from a high-quality product. Even so, quality from the perspectives of the manufacturer and the customer could differ. In fact, a product is perceived as high quality if the consumers are satisfied upon consistently using of certain products. Quality is defined as a whole feature, product attributes and the effect given by the product altogether. In addition to this, if the price does not match with the quality, the possibility of customers in choosing another product is high. Price determines the consumer's satisfaction which eventually lead to the purchase makeup products (Jamaluddin \& Ahmad Anuar, 2018). Products with a well-established brand name are the most preferred by the customers to be purchased. This is due to the trust and loyalty that the brand invokes in them to consume. From the interview conducted, R1, R3, R4, R6, R7, R8, R9, R13, R15, R16, $\mathrm{R} 17, \mathrm{R} 18, \mathrm{R} 19$, and R20 chose quality as a factor of purchasing international brand makeup products as compare to other factors.

While R5, R6, R10, R13, R14, R15 and R19 reflect effectiveness is the factor in purchasing international brand makeup products. The effectiveness of makeup products includes the compatibility of the skin, reducing skin problems, covering wrinkle spots and the absence of negative effects. As a result, those makeup products will be safe to purchase and consume.

Then, the next factor of choosing international brand makeup products is the high level of confident that the products provide to the consumer. R11 mentioned that the international brand makeup products increased the confidence level upon consuming it. The respondent felt safe and halal ingredients will make them loyal to continue consuming the makeup products.

Besides, R2 and R6 mentioned that the international brand makeup products possess a wider range of selections of the products. The respondents felt that they could choose from the type of products itself or based on the functions of the products.

For the external factors, R2, R7 and R8 mentioned that influencers, such as makeup artists, internet celebrities, public figures, well-known entrepreneurs, bloggers, and Instafamous convinced them to choose international brand makeup products over the local one. One of the respondents said: “.... At first, I wanted to try it because the influencers reviewed the products, and after I used this brand, it becomes my favorite products instantly....".

Thus, most of the respondents consumed the products due to the review from the influencers they followed. They tend to trust the influencers rather than identify the status of products initially. Besides, the respondents described that the brand awareness also influenced the purchasing decision. R9 and R12 stated: “... I choose this product because it 
is a well-known brand and lots of my friends used it...." While, R11's described: "These products have been established and a lot of research has been done on it and that is why I trusted this brand".

\section{Challenges on Non-Certified Halal International Brand Makeup Products}

Despite the overwhelming demand for international makeup products, those noncertified ones could not deny the challenges which arises from the issues of halal certification and the ingredients, just to name a few.

\section{Halal certification}

Some of the international makeup producers and manufacturers did not apply for halal certification or halal logo on their products (Arbak et al., 2019). Given the significance of halal labelled cosmetics, the implementation of halal logo and marketing strategies are still hardly in place in the Malaysian cosmetics industry (Majid et al., 2015). Meanwhile, Hussin et al. (2013) stated that the labelling of halal logo and its significance to the purchase intention of halal products is positive. In a way, the faith in the authenticity of halal logo will increase the purchase intention of the consumers on halal products.

\section{Ingredients}

Oils, fats and proteins are the examples of crucial ingredients in cosmetics products that should be paid great attention to. Those ingredients must be detected to ensure if it is following the Islamic law. This is because cosmetics products which contains or contaminated with porcine-derived products is not halal. It is hard to identify international makeup products because of their questionable ingredients (Hashim \& Mat Hashim, 2013).

\section{Conclusion}

Back in the past, cosmetics were claimed to be used since Stone Age by Archaeological excavations (REF). For ancient people, the use of cosmetics were mainly for safety, sunlight's protection and for religious perspective. As the time passes, the purpose of cosmetics also changes. The modern people used cosmetics to make life more enjoyable and rewarding. This is where the international makeup products take place. Thus, many issues need to be tackled in Halal Cosmetics industry as it involved in the non-certified halal makeup products which been widely used among the Muslim consumers. Based on the findings, the factors influencing Malaysian Muslim women in choosing international makeup products are divided into internal and external factors. Internal factors include quality, trust, loyalty, effectiveness, brand, price, safety, ingredients, confident and wide range of products while for the external factor is solely from the influencer. This paper aims to create more market demand from those Muslim consumers for halal makeup products so that the international cosmetic companies will produce and adopt the halal certification requirements. 
Besides, it will increase the confidence of Muslim consumers in using international makeup products.

\section{Conflict of Interest}

The author declares that there is no conflict of interest in this work.

\section{Reference}

Ahmad, A. N., Rahman, A. A., \& Rahman, S. A. (2015). Assessing knowledge and religiosity on consumer behavior towards Halal food and cosmetic products. International Journal of Social Science and Humanity, 5 (1), 10-14.

Ali, S., Halim, F., \& Ahmad, N. B. (2016). Beauty premium and Halal cosmetics industry. Journal of Marketing Management and Consumer Behavior, 1(4), 52-63.

Arbak, S., Islam, R., \& Al-Rashid, H. (2019). Relationship between advertisement and purchase intention on Halal cosmetic products in Malaysia. Humanities and Social Sciences Reviews, 7 (3), 683-694.

Hassali, M., A., Al-Tamimi, S., Dawood, O. T., et al. (2015). Malaysian cosmetic market: Current and future prospects. Pharmaceutical Regulatory Affairs, 4(4), 4-6.

Babbie, E. R. (2016). The practice of social research (14 ${ }^{\text {th }}$ ed.). United State: Cengage Learning.

Elmarzugi, N. A., Keleb, E. I., Mohamed, A. T., et al. (2013). Face powder problems perception survey. International Journal of Pharmaceutical Science Invention, 2 (6), 9-18.

Ghafur, A. (2017). Awareness of Halal Cosmetics Products Among Students in Polytechnic of Sultan Haji Ahmad Shah, (June 2010), 1-14.

Hamedi, A., Trotta, F., Borhani Zarandi, M., et al. (2019). In Situ Synthesis of MIL-100(Fe) at the Surface of Fe $\mathrm{O}_{4} @ \mathrm{AC}$ as Highly Efficient Dye Adsorbing Nanocomposite. International of Journal Molecule Science 20, 5612.

Hashim, P., \& Mat Hashim, D. (2013). A review of cosmetic and personal care products: Halal perspective and detection of ingredient. Pertanika Journal of Science and Technology, 21 (2), 281-292.

Hashim, A. J. C. M., \& Musa, R. (2013). Modeling the effects on the attitude of young adult urban Muslim women towards Halal cosmetic products: New insights for championing the Halal economy. International Journal of Education and Research, 1(7), 1-8.

Hornby, A. S. (2010). Oxford's Advanced Learner's Dictionary (J. Turnbull, Ed.) ( $8^{\text {th }}$ ed.). New York: Oxford University Press.

Hussin, S. R., Hashim, H., Yusof, R. N., et al. (2013). Relationship between product factors, advertising, and purchase intention of Halal cosmetic. Pertanika Journal of Social Science and Humanities, 21(S), 85-100.

Jamaluddin, B., \& Ahmad Anuar, A. H. (2018). Mengkaji Faktor-faktor yang Mempengaruhi Kepuasan Pelanggan Terhadap Produk Kecantikan Berasaskan Herba. E-Proceeding National Innovation and Invention Competition Through Exhibition 2018.

Kaur, K. (2018). Is Halal a priority in purchasing cosmetics in Malaysia among Muslim Malaysian women? International Journal of Business, Economics and Law, 15 (3), 19-25.

Kaur, K., Osman, S., \& Maziha, S. (2014). Predicting working women purchasing behaviour of Malaysian Halal cosmetic products by using theory of planned behaviour. International Academic Research Journal of Business and Management, 3(January 2014), 1-7.

Lee, J. E., Goh, M. L., Mohd \& Noor, M. N. B. (2019). Understanding purchase intention of university students towards skin care products. PSU Research Review, 3(3), 161-178. 
Majid, M. B., Sabir, I., \& Ashraf, T. (2015). Consumer purchase intention towards Halal cosmetics \& personal care products in Pakistan. Global of Research in Business \& Management, 1(1), 45-53.

Mohezar, S., Zailani, S., \& Zainuddin, Z. (2016). Halal cosmetics adoption among young Muslim consumers in Malaysia: Religiosity concern, Global Journal al-Thaqafah, 6(1), 47-59.

Nassaji, H. (2015). Qualitative and descriptive research: Data type versus data analysis. Language Teaching Research. 19 (2), 129-132.

Phuah, K. T., \& Jusoh, W. J. W. (2013). Investigating student's awareness and usage intention towards halal-labelled cosmetics and personal care products in Malaysia. $4^{\text {th }}$ International Conference on Business and Economic Research (4 ${ }^{\text {th }}$ ICBER 2013) Proceeding, 367-376.

Swidi, A., Cheng, W., Hassan, M. G., et al. (2010). The mainstream cosmetics industry in malaysia and the emergence, growth, and prospects of halal cosmetics (pp. 1-20). In: The Third International Conference on International Studies (ICIS 2010). College of Law, Government and International Studies, Universiti Utara Malaysia.

Teoh, K. C., \& Md Harizan, S. H. (2017). Factors Influencing Consumers Purchase Intention of Cosmetic Products in Malaysia. International Journal of Business, 3(1), 1-15. Retrieved from http://www.theijbi.net/d1/vol3/issue12017/IJBI-Factors-Influencing-Consumers.pdf

Tim, M. (2011). Social research issues, methods and process ( $4^{\text {th }}$ ed.). England: Open University Press.

USA Food, Drug and Cosmetic Act 2012. US Food and Drugs Administration (FDA). Retrieved April 20, 2020, from https://www.fda.gov/cosmetics/cosmetics-laws-regulations/cosmetics-us-law\#:

Zaidun, N. A., \& Hashim, N. H. (2017). Halal Cosmetics : Current Issues and Concept of Halal Cosmetics, Jurnal Pengguna Malaysia. 74-80.

Copyright $(2) 2020$ by Idris NA et al. and HH Publisher. This work is licensed under the Creative Commons Attribution-NonCommercial 4.0 International License (CC-BY-NC4.0) 